\title{
Implementasi teknologi digital untuk meningkatkan kualitas sepatu pada Industri Kecil dan Menengah
}

\author{
Caecilia Sri Wahyuning*
}

Jurusan Teknik Industri Fakultas Teknologi Industri, Institut Teknologi Nasional, Bandung, Indonesia

\begin{abstract}
One important aspect in shoe design is a matter of comfort, which is determined by dimensions and the shape of shoe last which is influenced by the design of the master shoe last. The use of 3D scanners, 3D printers, and CAD / CAM systems in the process of master shoe last design and production of shoe last can improve the quality of shoe products. However, the application of technology to the IKM implies the need to increase HR capabilities and substantial investment. This indicates the need for involvement of government and institutions / $R \& D$ institutions or universities. Therefore, to improve the design of university competencies in mastering technology, curriculum needs to be designed that refers to the competence of designer work in accordance with the progress / development of digital technology in the process of design and production.
\end{abstract}

Key words: industry 4.0, Small and Medium Industries, master shoe last, quality

\begin{abstract}
Abstrak
Salah satu aspek penting dalam perancangan sepatu adalah masalah kenyamanan, yang ditentukan oleh dimensi dan bentuk shoe last yang dipengaruhi oleh rancangan master shoe last. Penggunaan 3D scanner, 3D printer, serta sistem CAD/CAM pada proses desain master shoe last dan produksi shoe last dapat meningkatkan kualitas produk sepatu. Namun demikian penerapan teknologi pada IKM mengisyaratkan perlunya peningkatan kapabilitas SDM dan investasi yang cukup besar. Hal ini mengindikasikan diperlukannya keterlibatan pemerintah dan lembaga/institusi litbang atau perguruan tinggi. Oleh karena itu, untuk meningkatkan kompetensi perguruan tinggi desain dalam penguasaan teknologi, perlu dirancang kurikulum yang mengacu pada kompentensi kerja desainer yang sesuai dengan kemajuan/perkembangan teknologi digital dalam proses desain dan produksi.
\end{abstract}

Kata kunci: industry 4.0, Industri Kecil dan Menengah, master shoe last, kualitas

\section{Pendahuluan}

Perubahan industri dunia yang memasuki pada revolusi industri ke-4, yang dikenal dengan Industry 4.0 memberikan dampak yang sangat besar dan luas. Dampak terhadap Industri di Indonesia mendorong pemerintah menerapkan Industry 4.0 dan meningkatkan investasi dan memanfaatkan peluang di era revolusi industri keempat. Konsekuensinya, pendekatan dan kemampuan baru diperlukan untuk membangun sistem produksi yang inovatif dan berkelanjutan (Kementerian Perindustrian Republik Indonesia, 2018).

Strategi yang diterapkan Indonesia untuk masuk dalam era Industri keempat adalah: (1) peningkatan keterampilan angkatan kerja dalam memanfaatkan teknologi internet of things (IOT) atau mengintegrasikan kemampuan internet dengan lini produksi di industri, (2) pemanfaatan teknologi digital untuk memacu produktivitas dan daya saing bagi industri kecil dan menengah (IKM), (3) tuntutan untuk memanfaatkan teknologi digital seperti Big Data, Autonomous Robots, Cybersecurity, Cloud, dan Augmented Reality, (4) inovasi teknologi melalui pengembangan startup dengan memfasilitasi tempat inkubasi bisnis.

Penerapan Industry 4.0 bukan hanya dapat mengoptimalkan dan menyederhanakan rantai pasok, digitalisasi juga akan membuka peluang pasar bagi penyedia teknologi seperti teknologi sensing, robotic,

\footnotetext{
* Corresponding author e-mail : caecil@itenas.ac.id
} 
$3 D$ printing, dan sebagainya. Oleh karena itu perlu peningkatan penguasaan teknologi sebagai penentu daya saing. Keberhasilan penerapan Industry 4.0 akan mendorong pertumbuhan Produk Domestik Bruto (PDB). Data tahun 2015 menunjukkan bahwa PDB Ekonomi Kreatif adalah 852 triliun rupiah, tumbuh sebesar 4,38\% (Badan Ekonomi Kreatif Republik Indonesia, 2017b). Namun demikian, dalam pemanfaatan teknologi informasi pada industri kreatif masih sebatas penggunaan komputer dan internet, untuk keperluan layanan surel (email), mencari informasi, melayani pelanggan (Badan Ekonomi Kreatif Republik Indonesia, 2017a), dan saat ini sudah masuk dalam ranah jual beli secara online.

Ekonomi Kreatif memberikan kontribusi sebesar 7,38 persen terhadap total perekonomian nasional. Kontribusi sub sektor fesyen berkontribusi terhadap PDB ekonomi kreatif sebesar $18.15 \%$. Dalam neraca ekspor nasional, fesyen merupakan ekspor ekonomi kreatif terbesar (56\%). Jawa Barat merupakan kota asal ekonomi kreatif dan terbesar memiliki produk ekonomi kreatif (Badan Ekonomi Kreatif Republik Indonesia, 2017b). Kota Bandung merupakan pusat industri kreatif di Indonesia, dengan produk sepatu sebagai salah satu industri fesyen yang berkembang. Akan tetapi persaingan dalam industri persepatuan menjadi sangat ketat dengan masuknya produk sepatu dari luar negeri dan produk lokal tidak mampu bersaing.

Selaras dengan penerapan Industry 4.0 maka pemanfaatan teknologi digital dapat membantu Industri Kecil Menengah (IKM) di Bandung untuk meningkatkan daya saing. Akan tetapi, karena pada umumnya pengusaha dalam industri kreatif telah memanfaatkan teknologi informasi dalam menjalankan usahanya, perlu ditelusuri teknologi yang masih dapat dimanfaatkan dan menjadi solusi dalam permasalahan di industri persepatuan.

Pada umumnya konsumen sepatu lokal memiliki ketidakpuasan terhadap beberapa aspek sepatu yang mereka gunakan. Aspek kenyamanan, kesesuaian bentuk sepatu dengan kaki, dan desain sepatu merupakan aspek dengan ketidakpuasan yang tinggi pada pengguna sepatu olah raga (Azhari, Wahyuning, \& Irianti, 2015). Demikian pula pada pengguna high heel, sebagian besar ketidakpuasan terdapat pada aspek estetika dan kenyamanan sepatu (Waskito \& Wahyuning, 2013).

Secara umum perancangan alas kaki masih mempertimbangkan aspek fashion/tampilan/ estetika. Masih belum banyak penelitian yang mempertimbangkan ergonomi dan menjadi penyebab permasalahan kaki (Lin \& Chen, 2015) dan kenyamanan, termasuk bagaimana sebuah rancangan sepatu dapat menimbulkan cidera (Barnish \& Barnish, 2016). Faktor yang berkontribusi terhadap estetika dan keamanan/kenyamanan sepatu adalah model sepatu, dimensi dan bentuk kaki, bentuk pola, bahan, dan proses perakitan sepatu (Azhari et al., 2015; Waskito \& Wahyuning, 2013). Secara lebih spesifik kenyamanan dan keamanan (dari cidera) dari sepatu ditentukan oleh bentuk shoe last (Waskito \& Wahyuning, 2013).

Permasalahan lain yang muncul pada konsumen adalah konsumen tidak memiliki kepastian terhadap nomor kakinya. Kondisi ini menyebabkan konsumen harus mencoba beberapa sepatu dengan nomor berbeda untuk model yang sama saat membeli sepatu. Hal ini mengindikasikan bahwa sistem penomoran sepatu tidak seragam. Proses penomoran sepatu terjadi di pengrajin shoe last, yang merupakan proses duplikasi/replikasi master shoe last. Dalam produksi massal, master shoe last tersebut akan dibuat dalam bentuk grading shoe last, yaitu membuat shoe last dengan penomoran. Selain itu masih banyak produk sepatu yang tidak menyediakan sepatu dengan nomor bulat. Hal ini berdampak pada konsumen yang memiliki nomor sepatu di antara nomor bulat harus memilih menggunakan nomor dengan $1 / 2$ nomor lebih besar. Kondisi berpengaruh terhadap ketidaknyamanan.

\section{Bahan dan metode}

Industri-industri kecil di Indonesia umumnya menggunakan sistem penomoran French/ Europe Sizes. Pada sepatu dengan target pasar lokal sistem pengukuran menggunakan sistem metrik/mondopoint, yang terlepas dari standar internasional (Waskito \& Wahyuning, 2013). Hasil penelitian menunjukkan bahwa terdapat kecenderungan ukuran sepatu partisipan tidak sesuai dengan ukuran sepatu berdasarkan mondopoint/Eropa. Ukuran foot length pada sebuah nomor sepatu lebih kecil dari ukuran berdasarkan sistem mondopoint/ Eropa (Gambar 1). Terdapat perbedaan yang signifikan $(\mathrm{p}<0,05)$ antara foot length hasil pengukuran dengan ukuran berdasarkan sistem mondopoint atau Eropa. Sebagai contoh, foot length pada sistem mondopoint (berdasarkan International Shoe Size Convertion Chart) untuk nomor 351/2 adalah $228 \mathrm{~mm}$, sedangkan Rata-rata foot length hasil pengukuran partisipan dengan nomor sepatu 351/2 adalah 21,4 cm (214 mm).

Dalam perancangan shoe last, dimensi antropometri kaki yang juga perlu diperhatikan adalah keliling ball (ball girth) dan panjang kaki (foot length). Gambar 2 menunjukkan rasio ball girth dan 
foot length, terdapat sebaran yang mengindikasikan pentingnya pembuatan shoe last untuk kaki kurus (slim feet), kaki normal, dan kaki lebar (bare feet). Oleh karena itu pada proses pembuatan shoe last, tahap pembuatan grading nomor tidak dapat dilakukan secara masinal.
Bila mengacu pada hasil pengukuran antropometri kaki, ketidakseragaman ukuran dan bentuk pada shoe last bersumber dari rancangan master shoe last.

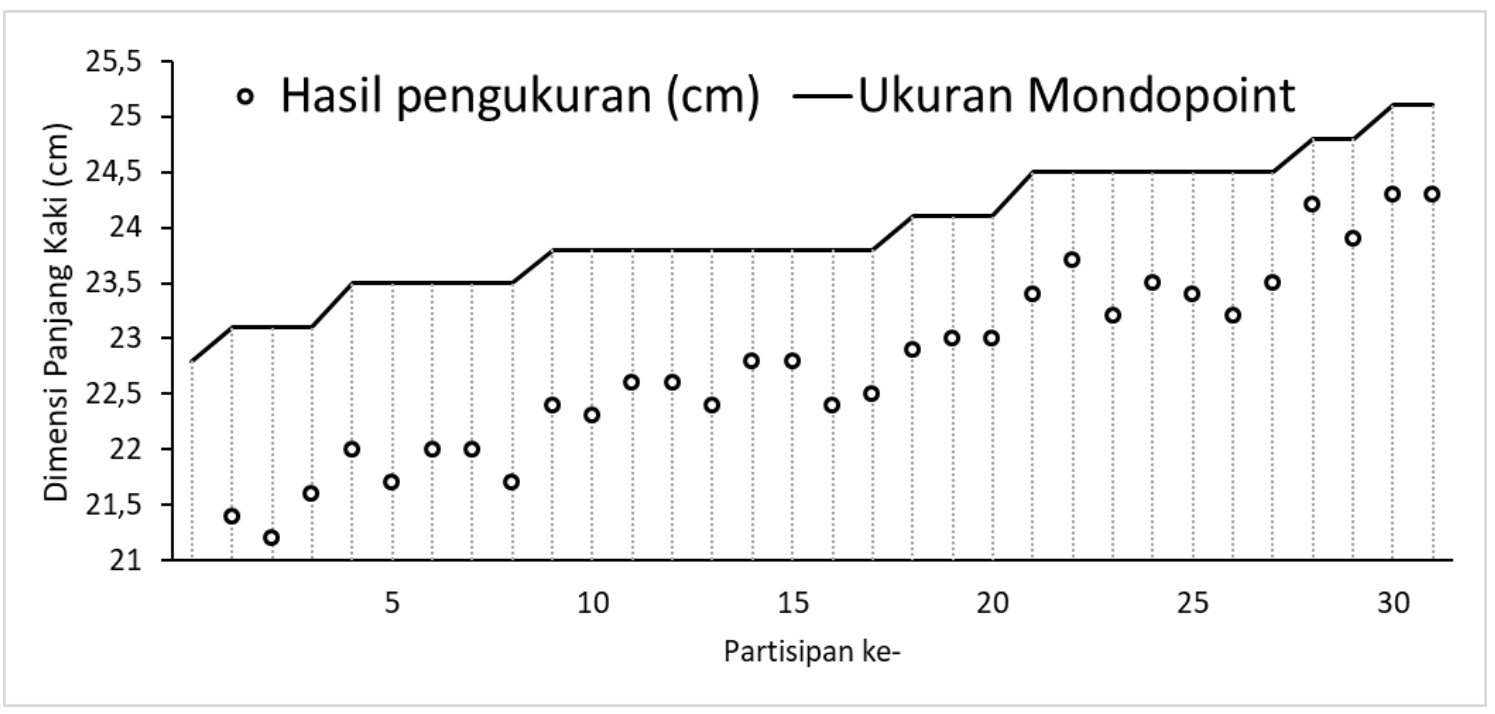

Gambar 1. Posisi Hasil Pengukuran Terhadap Ukuran Mondopoint

Pada shoe last terdapat ketidaksesuaian bentuk shoe last dengan karakter kaki dan data antropometri yang diperoleh, sehingga perlu penyesuaian pada area punggung kaki, lengkungan kaki (arch) pada bagian plantar, dan bagian atas tumit. Kajian pada rancangan master shoe last menemukan bahwa titik kritis rancangan master shoe last terdapat pada bentuk toe box atau bagian depan sepatu, bentuk boe box, terutama pada shoe last untuk high heel, dan bentuk back counter atau tumit master shoe last untuk sepatu jenis pump.

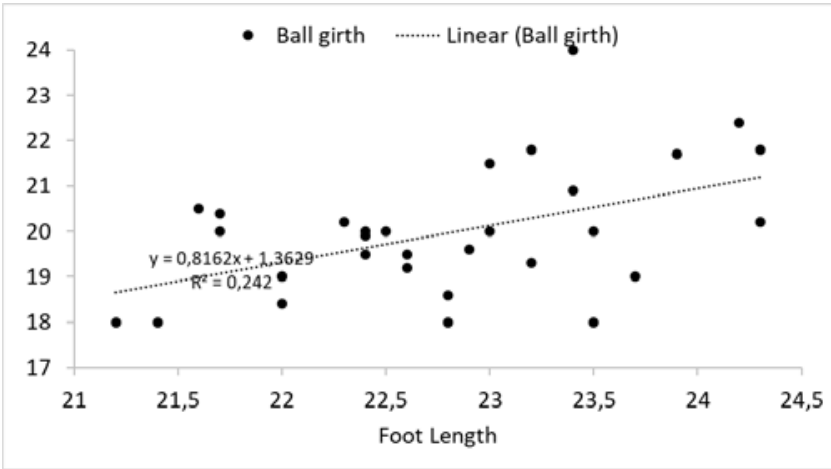

Gambar 2. Rasio ball girth dan foot length

\section{Hasil dan pembahasan}

Ukuran sepatu tergantung pada desain, bentuk, dan volume shoe last (Chen, Gong, Jin, \& Tong, 2005), dan kaki manusia adalah bentuk 3D yang sangat kompleks dan fleksibel serta bervariasi pada setiap individu (Lochner, 2009). Shoe last harus mewakili informasi anatomi kaki, sehingga sepatu yang digunakan sesuai dengan keinginan konsumen. Metoda pemesinan tradisional shoe last hanya menggunakan mesin pengganda mekanis, dan masih terdapat proses manual. Hal ini dapat berdampak pada kualitas dan kuantitas shoe last. Sistem CAD/CAM yang terintegrasi pada pembuatan shoe last merupakan teknologi yang dapat menghasilkan produk shoe last yang sangat efektif dan efisien, dengan sistem ini dapat dihasilkan produk yang sangat berkualitas dalam waktu yang tidak terlalu lama. Teknologi ini pun sangat cocok dalam pendekatan pengembangan dan produksi shoe last (Chen et al., 2005).

Mengacu pada permasalahan pembuatan master shoe last serta penomoran dan pembentukan shoe last, maka teknologi yang dapat diterapkan pada proses produksi shoe last dan master shoe last adalah 3D scanner (pemindai) dan 3D printer (pencetak). 
Teknologi ini telah diterapkan pada industri sepatu besar di luar negeri, sedangkan di Indonesia masih belum banyak industri yang memanfaatkan teknologi ini. Sistem pemindaian permukaan 3D dapat memberikan represensasi digital yang akurat dan berulang dari bentuk kaki. Lebih jauh lagi, pemindaian 3D dan CAM telah merevolusi pembuatan sepatu, mempercepat proses desain shoe last dan meningkatkan ketepatan pengukuran. Hal ini berdampak terhadap kualitas secara keseluruhan, termasuk kenyamanan.

Titik kritis pembuatan master shoe last terdapat pada bentuk toe box atau bagian depan sepatu, bentuk boe box, dan bentuk back counter. Kondisi ini sering terjadi karena ketiga titik ini dipengaruhi oleh posisi kaki saat menggunakan alas kaki, oleh karena itu pemanfaatan 3D Scanner dapat mendeteksi bentuk kaki dengan berbagai posisi kaki. Sebagai contoh, posisi kaki saat menggunakan high heel akan mempengaruhi bentuk boe box.

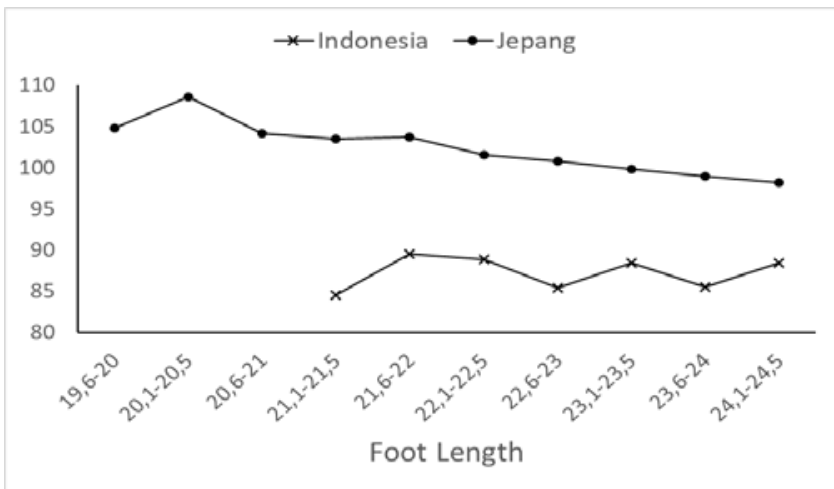

Gambar 3. Rasio ball girth dan foot length wanita Indonesia dan Jepang

Pemanfaatan 3D scanner dapat digunakan untuk mendapatkan dimensi-dimensi kaki secara lebih akurat, selain itu bentuk yang diperoleh pun sesuai dengan karakter kaki orang Indonesia. Sebagai contoh, terdapat perbedaan anatomi kaki wanita Perancis dan Jepang. Indonesia dengan wanita Jepang, Rasio ball girth dan foot length wanita Jepang lebih besar dari wanita Perancis (Baba, 1975), dan rasio ball girth dan foot length wanita Indonesia lebih kecil dari wanita Jepang (Gambar 3) (Waskito \& Wahyuning, 2013).

Data hasil 3D scanner dapat digunakan untuk menentukan penomoran yang lebih sesuai dengan standar yang digunakan industri persepatuan di Indonesia (sistem pengukuran Mondopoint atau Eropa). Pemanfaatan 3D scanner bukan hanya untuk menentukan penomoran, secara lebih spesifik teknologi ini dapat menggambarkan kelainan-kelainan bentuk kaki seperti bunion, pronasi-supinasi, flat feet dan sebagainya. Dengan kemampuan ini maka konsumen memiliki pemahaman yang lebih seksama terhadap kakinya, sehingga dapat memilih sepatu sesuai dengan kondisi kakinya.

Keterampilan perancang dalam penggunaan software/perangkat lunak dapat meningkatkan produktivitas secara signifikan. Pemanfaatan program/software membantu pembuatan master shoe last khusus (customized) berdasarkan data base/ "pustaka" shoe last dengan cepat dan mudah. Software diintegrasikan dengan hasil pemindaian 3D dari jejak, dimensi, berat dan persyaratan klinis dari alas kaki dalam proses desain yang terkomputerisasi. Data desain ini selanjutnya dikirimkan pada manufaktur atau pengrajin.

Pemanfaatan 3D printer pada industri sepatu dapat meningkatkan kecepatan dan ketepatan produksi shoe last, terutama berkaitan dengan biaya. Teknologi ini dapat membantu proses pencetakan shoe last lebih cepat dan menyederhanakan siklus produksi. Salah satu kendala pengrajin sepatu adalah pengadaan shoe last untuk semua ukuran kaki, termasuk shoe last dengan ukuran 351/2. Hal ini menyangkut biaya pengadaan, sehingga pemanfaatan 3D printer dapat membantu memecahkan masalah ini.

Pemanfaatan yang lebih jauh adalah, dengan penggunaan 3D printer maka memungkinkan komunitas tertentu yang sangat berkaitan erat dengan industri sepatu dapat memiliki shoe last dan menggunakan shoe last untuk mendapatkan sepatu yang khusus untuk yang bersangkutan (customized), misalnya seorang model atau penggemar sepatu. Bahkan lebih jauh lagi, 3D printer dapat digunakan untuk memproduksi bagian-bagian alas kaki lain seperti insoles, midsoles atau outsoles. Kemampuan ini dapat membantu perancangan sepatu yang khusus bagi individu yang memiliki kekhususan dengan kaki, misalnya untuk kaki dengan kondisi pronasi, supinasi, dan sebagainya.

Secara lebih khusus, pemanfaatan 3D Scanner dan 3D printer dapat meningkatan peluang usaha bagi pengrajin sepatu untuk memproduksi sepatu khusus/sesuai dengan kondisi kaki konsumen (customized). Peluang ini dapat ditangkap sejalan dengan tren hidup sehat di kalangan masyarakat di kota Bandung. Bila saat ini tren hidup sehat masih sebatas pada pola makan dan olah raga, maka industri persepatuan dapat masuk ceruk pasar ini dengan pendekatan hidup sehat melalui gaya fesyen

\section{Konsekuensi penerapan teknologi}

Salah satu permasalahan belum banyaknya industri persepatuan di Indonesia yang menerapkan teknologi 
ini adalah pada aspek biaya dan penguasaan teknologi. Oleh karena itu perlu adanya peran dari Unit Pelayanan Teknik (UPT) untuk memfasilitasi teknologi ini. Kurangnya pengalaman praktis berdampak pada implementasi teknologi, sehingga perlu upaya untuk mengembangkan kemampuan secara efektif untuk mengadaptasi teknologi produk dan proses.

Didorong oleh permintaan terhadap produk yang berkualitas maka perlu adanya pendampingan terhadap IKM, termasuk dalam implementasi teknologi produk dan proses. Konsekuensi penerapan teknologi dalam sebuah industri kecil adalah pada aspek finansial dan sumber daya manusia. Meningkatkan performansi UPT untuk menjalin kerja sama yang diarahkan untuk mendapatkan pada bantuan atau insentif serta pendampingan. Kerja sama dengan pemerintah/dinas maupun lembaga/instansi (lembaga litbang atau perguruan tinggi) diharapkan dapat merealisasikan konsep penerapan teknologi sebagai layanan terhadap IKM persepatuan. Kemudahan akses dan menggunakan teknologi pada IKM akan meningkatkan daya saing, sehingga dapat mentransformasi ekonomi Indonesia ke arah yang lebih maju. Kemajuan ini akan mendukung pertumbuhan secara inklusif yang melibatkan seluruh lapisan ekonomi masyarakat (Triwijanarko, 2018).

Implikasi perguruan tinggi sangat besar dalam penerapan teknologi di IKM, sehingga perguruan tinggi pun perlu disiapkan untuk menghadapi revolusi industry 4.0 ini, termasuk program studi desain. Oleh karena itu program studi desain perlu memperkenalkan perkembangan teknologi yang dapat digunakan dalam proses desain dan produksi bahkan dalam proses pemasaran. Mahasiswa perlu diperkenalkan dengan software dan hardware yang dapat digunakan dalam proses desain dan produksi, sehingga akan diperoleh produk yang jauh lebih inovatif. Konsep pembelajaran teknologi digital dalam desain dan produksi pada mahasiswa akan meningkatkan kompetensi desainer.

\section{Kesimpulan}

Upaya yang dapat dilakukan untuk meningkatkan daya saing industri kecil dan menengah (IKM) persepatuan adalah dengan meningkatkan kualitas produk. Salah satu aspek yang mempengaruhi kualitas sepatu adalah ketidaknyamanan yang disebabkan oleh rancangan dan standarisasi master shoe last dan shoe last yang tidak sesuai dengan karakter kaki orang Indonesia. Penerapan teknologi digital merupakan salah satu alternatif solusi yang dapat membantu meningkatkan daya saing IKM. Dalam kasus ini penerapan teknologi dapat membantu proses perancangan dan standarisasi master shoe last dan meningkatkan produktivitas produksi shoe last.

Perlu upaya untuk meningkatkan kemampuan SDM, sehingga peran pemerintah dan lembaga/institusi diharapkan dapat membantu penerapan teknologi di IKM. Namun demikian, agar dapat berperan dalam pengembangan IKM, lembaga/institusi (perguruan tinggi) perlu terlebih dahulu menguasai teknologi terkait. Oleh karena itu perlu dirancang kurikulum yang mengacu pada kompetensi kerja seorang desainer yang sesuai dengan kemajuan/perkembangan teknologi digital dalam proses desain dan produksi.

\section{Daftar pustaka}

Azhari, M. A., Wahyuning, C. S., \& Irianti, L. (2015). Rancangan produk sepatu olahraga. Reka Integra, 3(4), 241-252.

Baba, K. (1975). Foot measurement for shoe construction with reference to the relationship between foot length, foot breadth, and balll girth. Journal Human Ergology, 3, 149-156.

Badan Ekonomi Kreatif Republik Indonesia. (2017a). Data Statistik dan Hasil Survei Ekonomi Kreatif. Jakarta.

Badan Ekonomi Kreatif Republik Indonesia. (2017b). Peraturan Kepala Badan Ekonomi Kreatif Republik Indonesia No 8 Tahun 2017 tentang Rencana Strategis Badan Ekonomi Kreatif Tahun 2015-2019. Jakarta, Indonesia.

Barnish, M. S., \& Barnish, J. (2016). High-heeled shoes and musculoskeletal injuries: a narrative systematic review. BMJ Open, 6(1), e010053. https://doi.org/10.1136/bmjopen-2015-010053

Chen, J., Gong, Y., Jin, T., \& Tong, S. (2005). Development of an integrated CAD/CAM system for shoe last. In IEEE International Conference Mechatronics and Automation 2005 (2) (pp. 11071111).

IEEE. https://doi.org/https://doi.org/10.1109/ICMA.2005.1626 706

Kementerian Perindustrian Republik Indonesia. (2018). Empat Strategi Indonesia Masuk Revolusi Industri Keempat. Retrieved September 23, 2018, from http://www.kemenperin.go.id/artikel/17565/EmpatStrategi-Indonesia-Masuk-Revolusi-Industri-Keempat

Lin, L.-Y., \& Chen, C.-H. (2015). Innovation and ergonomics consideration for female footwear design. Procedia Manufacturing, 3, 5867-5873. https://doi.org/10.1016/j.promfg.2015.07.891

Lochner, S. J. (2009). Automation of Shoe Last Modification Tool Path Planning. Thesis. University of Waterloo, Canada.

Triwijanarko, R. (2018). Presiden Minta Implementasi 
Industri 4.0 bisa dirasakan Pelaku UKM. Retrieved April 5, 2018, from http://marketeers.com/presidenmeminta-implementasi-industri-4-0-juga-dirasakanoleh-pelaku-ukm/

Waskito, M. A., \& Wahyuning, C. S. (2013). Perancangan Master Shoe Last sebagai Usaha Meningkatkan Kualitas Ergonomi Produk Sepatu Wanita yang Dikembangkan Melalui Metoda Quality Function Deployment. Bandung: LPPM Itenas. 